\title{
Relacje orientalistyczne o Japonii a gra w antyinformację - studium przypadku
}

Orientalism-based accounts on Japan and anti-information game - case study

\section{Arkadiusz Jabłoński}

Uniwersytet im. Adama Mickiewicza w Poznaniu yaboo@amu.edu.pl | ORCID: 0000-0002-0812-4142

\begin{abstract}
Orientalism-based accounts (known as careless narrations) on Japan and on various manifestations of Japanese culture seem to constitute inevitable elements of social communication in an era of universality and the cyclical nature of mass communication. Thus, it may be worthwhile examining their informative value, especially due to the possibility of easy verification of source facts, also provided by the contemporary media-based society. In this paper, as examples of peculiar anti-information games, the orientalism-related accounts by Joanna Bator and Beata Pawlikowska available to Polish readers are presented. Despite the distinct factual carelessness visible at first sight in the analyzed texts, they seem to reveal the outlines of interesting trends in examining the world. This is achieved by the light-hearted and unrestrained (although not always unproductive) ludic creative activity, of which they are a genuine and unconsidered expression.
\end{abstract}

Keywords: communication games, inter-cultural communication, orientalism, unproductivity 



\section{Bezproduktywność gier}

Koncepcja gier jako przejawów aktywności nadmiarowej zostanie niżej wykorzystana do opisu aktywności komunikacyjnej w kontekście z założenia międzykulturowym. Podobnie jak w innych artykułach tego samego autora dotyczących gier, również w niniejszym tekście traktowane one będą jako aktywności ludyczne (Caillois, 1997; Huizinga, 1985), semiologiczne (Guiraud, 1974), teatralne (Goffman, 2000) i psychologiczne (Berne, 1999). Ponadto z punktu widzenia aktywności komunikacyjnej gry postrzegać można poprzez pryzmat osiągania celów - jako procedury (Austin, 1962) dotyczące rzeczywistości dnia codziennego (Berger, Luckmann, 1983), a także fatycznych cech przekazu (Jabłoński, 2009).

Opozycja między grami a rzeczywistością przejawia się również w aktywności odnoszonej do turystyki - swoistego podgatunku komunikacji międzykulturowej, w której ramach rozmaite prawdziwe elementy rzeczywistości, wykazujące weryfikowalne właściwości, postrzegane są z punktu widzenia turysty jako ich swoiste, tymczasowe alter ego. Mechanizm taki zaobserwować można w działaniach turystów, które nie muszą wykazywać cech produktywnych (MacCannell, 2005, s. 15). Turysta-konsument niekoniecznie rozumie wszystkie aspekty tworzonego dla niego spektaklu (Ritzer, 2012, s. 183 i in.). Jako skutek uboczny tak postrzeganej aktywności wymienić można też funkcjonowanie rozmaitych desygnatów (znanych jako destynacje turystyczne), w tym również samej Japonii, w roli elementów swoistej gry informacyjnej - już niekoniecznie bezproduktywnej. Jak ujmuje to źródło klasyczne, nurt orientalizmu "tworzy «ludzi Orientu», w pewnym sensie zaprzeczając ich człowieczeństwu" (Said, 2005, s. 63).

\section{Bezproduktywność}

Bezproduktywność jako maniera narracyjna bazuje niezbędnie na cechach wzmiankowanej wyżej rzeczywistości dnia codziennego (Berger, Luckmann, 1983), w tym na produktywności odnoszonej do kształtowania nadrzędnej rzeczywistości orzekania. W zasobie tekstów międzykulturowych 
funkcjonują trzy podstawowe gatunki relacji: fachowe, niefachowe i niedbałe (Jabłoński, 2016). Pierwsze z nich przedstawiają fakty. Można je produktywnie weryfikować - zgodnie z obowiązującą w ramach rzeczywistości życia codziennego dychotomią prawdy i fałszu. Drugie zawierają fakty naznaczone subiektywną, acz konwencjonalną interpretacją. Cechują się weryfikowalnością w ramach szczegółowej, bezproduktywnej z zasady, konwencji orzekania: żartu, anegdoty, dowcipu, hiperboli, poezji czy beletrystyki. Relacje niedbałe opierają się na mniej lub bardziej uświadamianej koncepcji gry kompensacyjnej w alter ego. Weryfikowalne pozostają jedynie w granicach umysłu autora - niekoniecznie na poziomie orzekanych faktów (nierzadko wręcz: antyfaktów). W toku takich relacji odbiorca nader często napotyka elementy antyinformacji. Ta zaś łatwo przeradza się w dezinformację, i to taką o charakterze wyraźnie orientalistycznym i ksenofobicznym.

\section{Relacje przykładowe}

Analizowane teksty polskie o Japonii pochodzą z ostatnich kilkudziesięciu lat. Eksponowane w nich są głównie wątki relacji niefachowych i niedbałych. Te uznawane - w ramach proponowanej terminologii - za fachowe, nacechowane intersubiektywną weryfikowalnością, przyjmują w przedstawianych fragmentach raczej rolę tła niż pierwszoplanową. W celu ich ramowego przeglądu dobrano je (co nie było zabiegiem trudnym w realizacji) według odniesienia do stolicy Japonii - Tokio. Przymiotniki występujące w tytułach dalszych podsekcji na pozycjach ostatnich nie stanowią ścisłych sugestii terminologicznych i odnoszą się do doraźnej, subiektywnej klasyfikacji podtypu relacji na tle pozostałych tekstów analizowanych w proponowanym zestawie.

\subsection{Relacja niefachowa neutralna}

Najstarsza z relacji wybranych tu do analizy pochodzi sprzed ponad pół wieku. Autorka to cudzoziemka z Europy, zagubiona, a nawet zdegustowana egzotyką, lecz - sądząc po jej spostrzeżeniach - szczera i oryginalna. Oto fragment najwyraźniej celowo utrzymywany w konwencji niefachowej gawędy podróżniczej: 
Tak jak na całym świecie, w Tokio przed sklepami plotkują sąsiadki, a wokół bawią się i plączą pod nogami małe dzieci. Małe dzieci matki noszą na plecach. Ożywiony ruch uliczny, plątanina ludzi i pojazdów w ciasnych uliczkach, kurz, brud i zaduch to Tokio w dzień. Wieczorem za to miasto zmienia się w przedziwny sposób. W dzień brudne i nieciekawe, wieczorem staje się troszkę krainą z baśni. Śródmieście oświetlone jest wręcz fantastycznie tysiącami różnokolorowych neonów o najrozmaitszych, przedziwnych kształtach i barwach. Mienią się, wytryskują w górę, gasną i rozlewają kaskady różnobarwnych płomieni. Całe ulice obierają ten sam kolor neonu - np. bukiet konwalii, jakiegoś przedziwnego smoka itp. A tuż obok tej orgii wielkomiejskiego światła, na wąskich uliczkach, wielokolorowe, tradycyjne lampiony oświetlają wejście do maleńkich restauracyjek, barów i kawiarenek. Spoza przesłoniętych papierem okien sączy się łagodne światło, zaciera ostre kontury przedmiotów tak, że wszystko dokoła staje się jakieś tajemnicze, trochę niepokojące i dziwne (Gall, 1961, s. 14-15).

Przytoczony fragment pełni jednoznacznie raczej rolę przelotnej impresji niż doniesienia ściśle fachowego. Czytelnik może się z treścią zacytowanej wypowiedzi zgodzić lub nie, jednak nie zaburzy to zapewne - w sposób istotny - jego obrazu Japonii rzeczywistej.

\subsection{Relacja niefachowa nowoczesna}

Kolejna relacja pochodzi z lat 8o. ubiegłego wieku. Socjalistyczna dziennikarka „Trybuny Ludu” opowiada w tym fragmencie o kraju kapitalistycznym, przedstawiając obserwacje niewolne od skrzywienia ideologicznego, acz pod względem faktograficznym generalnie rzetelne - często aktualne i dziś. Oto przykład opowieści o dzielnicy Shinjuku, umiejętnie umiejscowionej na granicy między relacją fachową a niefachową:

Niektórzy piszą, że Tokio to miasto, które nie ma nocy. Nieprawda. Większość dzielnic i ulic bardzo wcześnie pustoszeje, cichnie, usypia. Ale Shinjuku, podobnie jak Shinbashi, rzeczywiście żyje non stop, przez całą dobę. Ma już, nie bardzo wiadomo, dlaczego, taką tradycję. A zaczęło się to w końcu XVI wieku, gdy dla podróżnych przybywających do ówczesnego Edo - bo tak ongiś zwało się to miasto, nim zostało stolicą - wybudowano tu domy noclegowe, które szybko zasłynęły ze złej reputacji. Szerzyła się tu ponoć tak „wielka rozpusta”, że w 1720 roku nakazano zamknąć wszelkie oberże i zajazdy, a tłumy „kelnerek” obsługujących gości zarejestrowano jako prostytutki i skierowano do domów publicznych. Na sto pięćdziesiąt lat we wsi Shinjuku zapanowała cisza. Kiedy w 1888 roku jej mieszkańcy dowiedzieli się, że ma tu być wybudowana stacja kolejowa, posypały się protesty, gdyż twierdzono, że może to wpłynąć fatalnie na pola ryżowe (Rubach-Kuczewska, 1983, s. 52).

Trudno traktować przytoczony fragment jako w pełni fachowy i informatywny. Zarazem jednak autorka stosunkowo konsekwentnie oddziela w nim własne zdanie od informacji podlegających ścisłej weryfikacji. 


\title{
3.3. Relacja niedbała zwodnicza
}

Wypowiedź kolejna pochodzi z początku obecnego wieku, od autorki znanej z późniejszych dokonań literackich, poprzedzonych jednak stylizowanymi na pseudonaukowe doniesieniami na temat japońskiej egzotyki. Jak głosi notka na okładce przywoływanej książki (określanej tu metonimicznie mianem „Bator «wczesnej»”), to swobodna relacja z pobytu w Japonii, podparta rzekomą pracą naukową „na jednej z tokijskich uczelni” (nie zostaje zdradzona czytelnikowi jej nazwa) (Bator, 2004, okładka). Choć autorka sama ochoczo i niejeden raz akcentuje, że jest feministką i doktorem kulturoznawstwa, jej publikacja okazuje się niewolna od przeinaczeń i nieuprawnionych uogólnień. Tak źródło to opisuje adresy japońskie w Tokio, gdyż podróżniczka najpewniej donikąd indziej w Japonii dotrzeć nie zdołała:

\begin{abstract}
Uzasadnienie konieczności mapek jest proste, choć zaskakujące dla cudzoziemca. Otóż w Tokio, mieście, które jest tak wielkie, że nie wiadomo, gdzie się kończy, a gdzie zaczyna, ulice nie mają nazw. Nadaje się je tylko wielkim arteriom albo głównym pasażom handlowym, a cała reszta ulic pozostaje bezimienna. Ulice nie mają również numerów i nie są w ogóle punktem odniesienia. Zamiast tego miasto podzielone jest na jednostki administracyjne, coraz mniejsze kwadraciki, w których zagubiony wędrowiec szuka właściwego miejsca aż do momentu, gdy po prostu musi zapytać o drogę. Im bowiem bliżej celu, tym zadanie trudniejsze. W związku z tym w Tokio co prawdopodobnie czyni je wyjątkowym w skali światowej - to pasażer taksówki zobowiązany jest wiedzieć, jak dotrzeć do danego miejsca, a nie jej kierowca. Nawet komputer pokładowy bardziej nowoczesnych taksówek nie zawsze pomaga. Za czasów szogunów specjalnie budowano ślepe zaułki, uliczki kręcące się w kółko jak pies za własnym ogonem i kończące murem w tym samym miejscu, w którym się dwie godziny temu zaczęły [...] (Bator, 2004, s. 46-47).

Po drugiej wojnie światowej Amerykanie usiłowali wprowadzić w Tokio zachodni system i uporządkować adresy według zasad, które nam wydają się praktyczne i racjonalne. Ulice miały mieć numery, co pozwoliłoby każdemu przeciętnie inteligentnemu człowiekowi trafić wszędzie bez problemu i angażowania osób trzecich. Po odejściu Amerykanów Japończycy wrócili jednak do starych zwyczajów i nadal rysują mapki. Jak pisze Barthes w Imperium znaku [sic! - A. J.], w Japonii trzeba przyzwyczaić się do tego, że „to, co najbardziej praktyczne, nie musi być najbardziej racjonalne”, a Tokio to miasto, które „można poznać tylko przez działanie typu etnograficznego” i brnąc w dżungli znaków, szukać drogi (tamże, s. 50-51).
\end{abstract}

Relacji, pełnej zmyśleń, których nie warto omawiać dokładniej, towarzyszy mapka z anglojęzycznym podpisem: „For Joanna-san” (tamże, s. 47). Charakterystyczne, że Bator, opanowana przez manierę krytyki 
egzaltowanie niedbałej, nie dostrzega powiązania mapki z troską jej twórcy o gościa, który, pozbawiony takowej, mógłby dotrzeć na umówione miejsce później - lub nie dotrzeć w ogóle. Miast tego autorka przekonuje czytelnika o zmyślonym braku logiki w strukturze japońskich adresów, dostosowanej doskonale do gęstości zaludnienia w Japonii. Mapki w istocie nie są - w Tokio ani poza nim - używane do wskazywania punktu docelowego częściej niż w polskich realiach. I wcale nie częściej pyta się w Japonii o drogę - wystarczy odnaleźć odpowiedni numer w adresie, co autorce najwyraźniej umyka. Dżungla znaków nie istnieje.

\subsection{Relacja niedbata kakofoniczna}

Bator „późna” uprawia - w charakterystycznej aroganckiej manierze agresywnej niedbałości formulacyjnej - swoistą pseudohumanistykę stosowaną. W kolejnym źródle, z odpowiednio prowokacyjnym tytułem, autorka funkcjonuje jako „kulturoznawczyni i filozofka, która porzuciła karierę naukową dla literatury" (Bator, 2014, s. 2). Tekst zawiera pouczający fragment na temat rzekomej wszechobecności w Tokio tzw. Lolit (właściwie: lolit), nacechowany aż nader wyraźnie znamionami niedbałego bełkotu:

Są w Tokio sklepy dla Lolit, a opanowanie sztuki bycia Lolitą wymaga czasu i oddania sprawie. Nieporadna, zbyt wyzywająca czy tania Lolita określana jest pogardliwie jako ita. Nie trzeba być piękną, nie są wymagane idealne rysy i zgrabne nogi, bo liczy się opanowanie roli i umiejętność noszenia kostiumu. Wśród Lolit [...] zdarzają się mężczyźni. Nie ma na ich temat opracowań etnograficznych, nie są tak mili, by zbierać się w jednym miejscu i pozować do zdjęć jak niegdyś dziewczęta na mostku Jingu. Wielu mogło minąć mnie na ulicach Tokio i ujść za dziewczyny. Brat Lolita, którego kilka razy widziałam w Shibui, postury słusznej, z twarzy podobny do Takashiego Kitano, to raczej wyjątek wśród młodych zwykle Lolit płci obojga. Bracia Lolita w różach i koronkach spacerują po mieście wystawieni na spojrzenia ludzi. O to chodzi. Bez kostiumu jest się brzydkim facetem w średnim wieku albo młodym pracownikiem poczty, w kostiumie - słodką Lolitą, podobnie jak aktor kabuki z pana w starszym wieku cierpiącego na bóle żołądka zamienia się w targaną rozpaczą kurtyzanę o przenikliwym głosie (Bator, 2014, s. 36).

Niezmiernie trudno uznać, by tzw. lolity, pomimo odrębnych cech tej subkultury, były w Tokio zjawiskiem charakterystycznym, nawet w bardzo nielicznych miejscach, gdzie można je napotkać. Bator nie dba jednak o fakty, odnosząc się już nawet nie do żeńskich przedstawicielek grupy, lecz przedzierzgając - z charakterystyczną niedbałością - jednego „brata 
Lolitę" w tabuny dwupłciowych Lolit. Z iluzorycznej wielości wysnuwa zaś gładko dalsze wnioski, poruszając się w stworzonej przez siebie samą rzeczywistości na zasadach właściwie dowolnych.

\subsection{Relacja niefachowa gtupiutka}

Najnowsza z przytaczanych relacji to produkt flagowy formatu koncernu wydawniczego, który lokalizuje swe produkty w Polsce. Książka - jedna z serii dzieł Beaty Pawlikowskiej poświęconych z założenia egzotycznym, odległym miejscom na świecie - już na okładce przedstawia się jako sensacyjna i zaskakująca:

Kto nie słyszał o cudownie zdrowym japońskim jedzeniu, o samurajach, gejszach [...]? O japońskiej tradycji, kulturze i niezwykłej religii shinto?... [...] O zapasach sumo, sushi i słynnej japońskiej herbacie?

Ja słyszałam. Pojechałam do Japonii.

I OKAZAŁO SIĘ, ŻE WSZYSTKO JEST INACZEJ!!!!!! (Pawlikowska, 2016, okładka)

W innym miejscu autorka wyjaśnia genezę instytucji gejsz:

Zacznę od tego, że pierwsze gejsze były mężczyznami.

Działo się to w czasach szogunów z klanu Tokugawa, tych samych, którzy rozpoczęli najbardziej niezwykły okres w historii Japonii, zwany Edo. To była jednocześnie ówczesna nazwa Tokio.

Szogun miał władzę absolutną. Teoretycznie podlegał cesarzowi, ale w praktyce to on podejmował decyzje dotyczące wszelkich aspektów życia w swoim regionie.

Było to w czasie, kiedy Japonia odcięła się od reszty świata. Zamknęła swoje granice i po prostu skoncentrowała się na własnym rozwoju.

Nie tylko na pracy. Także na sztuce. Poezji, literaturze, teatrze, tańcu, muzyce. I na rozrywkach. Bo ciężko pracujący kupcy oraz wierni służący samurajowie potrzebowali czasem odpocząć.

Dla nich urządzono specjalną „dzielnicę przyjemności” - Yoshiwara. Były tam setki kurtyzan oczekujących na klientów. Wiele z nich było niewolnicami systemu.

W Yoshiwara można też było dobrze zjeść, wypić i oglądać występy klaunów oraz innych artystów, którzy występowali na scenie ku uciesze widzów. W tych rolach pojawiali się wyłącznie mężczyźni. Aż do pewnego dnia, kiedy na scenę wyszła kobieta (Pawlikowska, 2016, s. 165).

Pomimo wyraźnej przewagi maniery relacji niedbałej czytelnik nie doświadcza trudności w rozpoznaniu w tekście (raczej celowego) niefachowego odniesienia do beztroskiej, czującej się wszędzie tak samo obco, a zarazem znajomo, pozbawionej potrzeby głębszej refleksji nad rzeczywistością postaci tytułowej turystki-,,blondynki”. Trudno tu mówić 
o dezinformacji. Utrzymany przez ponad 300 stron książki niefrasobliwy i niewymagający styl, przywodzący na myśl klechdy przeznaczone dla niepiśmiennej dziatwy przedszkolnej, funkcjonuje jako skuteczna bariera, precyzując zawczasu profil potencjalnego odbiorcy tekstu i jednoznacznie sugerując, że próżno informacje zawarte w tym źródle traktować jako nacechowane fachowo.

\section{Zamiast konkluzji}

Pierwszą, do pewnego przynajmniej stopnia zaskakującą, konkluzję na temat zaprezentowanego zestawienia pięciu - pochodzących z ostatnich kilkudziesięciu lat - polskich relacji niefachowych na temat Japonii sformułować można, stwierdzając: czas i postęp techniczny nie wpływają automatycznie na lepszą jakość realizacji gatunku. A przecież w narracjach mniej i bardziej fachowych można również napotkać sugestie, jakoby tworzenie się tego, co określa metafora globalnej wioski, przyczyniało się do zbliżania się kultur.

Narracje fachowe ograniczają się do kontekstów informatywnych. We wskazanych książkach są to wydzielone sekcje zawierające konkretne dane liczbowe lub rozstrzygające o weryfikowalnych fizykalnie właściwościach rzeczywiście istniejących obiektów. Fragmenty takie nie dominują w żadnej z narracji, choć przynajmniej w niektórych są wyraźnie zauważalne.

Niefachowość, definiowana jako niecałkowita odpowiedniość treści narracji wobec rzeczywistości, pozostaje dopuszczalna przy zachowaniu pewnej konwencji orzekania. Trudno jednak za takową uznawać regularne stosowanie fałszu i zmyśleń - zabiegów odmiennych ontologicznie od gier i przynoszących prawdziwe negatywne skutki antyinformacyjne. Pod tym względem nawet (wyuczona?) nieudolność formulacyjna tekstu Pawlikowskiej wykazuje więcej cech konwencjonalnej relacji niefachowej od dzieł autorstwa Bator - wyraźnie nastawionych na dezinformację i w ramach proponowanej tu metodologii kwalifikowanych jednoznacznie jako narracje niedbałe. Bator ponadto, w opozycji do Pawlikowskiej, w manierze celowej i powtarzalnej w jej tekstach sugeruje rzekome naukowe umocowanie treści proponowanych czytelnikowi, co pozwala dopatrywać się w jej 
publikacjach znamion zamierzonej manipulacji. Prawdopodobnie zabieg taki nie służy celom szerzej zakrojonym metodologicznie, ale ma jedynie maskować powierzchowność styczności Bator z japońską rzeczywistością dnia codziennego, a może zwyczajnie znikomość ochoty tudzież zdolności autorki do zainteresowania się tą rzeczywistością. Wobec ewidentnego lekceważenia prawdy na temat Japonii przez Bator wypadałoby zadumać się nad sensownością ogniskowania tematyki dotychczasowych i przyszłych niebeletrystycznych tekstów pisarki na tematyce japońskiej.

Niewykluczone, że relacje dotyczące Kraju Kwitnącej Wiśni rozwijają się tak, jakby zmierzały do powstania nowej antyinformacyjnej gry. Gry, która jeszcze nie wyodrębniła się spośród innych - stąd jej przejawy pozostają siłą rzeczy pod wieloma względami niedoskonałe. Na jakich zasadach i w jakim celu jest ona prowadzona? Czy można wyjaśnić jej genezę i zastosowanie inaczej, niż wskazując na żerowanie na potencjalnym odbiorcy relacji niedbałych poprzez eksponowanie skandalicznych i egzotycznych aspektów komunikatu? O jednoznaczną odpowiedź trudno.

Zarazem antyinormacyjne praktyki Bator w dziedzinie regularnego kreowania relacji niedbałych na temat Japonii, obiecujące dużo więcej, niż czytelnik z nich uzyskuje, wydają się o wiele bardziej szkodliwe w perspektywie długofalowego kształtowania recepcji tego kraju w Polsce niż niewinne i naiwne, lecz pozbawione świadomego podszycia kłamstwem i przeinaczeniem, quasi-japonistyczne bajania Pawlikowskiej. W realiach komunikacji międzykulturowej wysnuwanie wniosków z nieistniejących przesłanek nie stanowi aktywności bezproduktywnej, powodując formowanie ksenofobicznego, z gruntu pozbawionego odniesienia do faktów, obrazu heterogenicznej kultury. Wpływ taki łatwo zignorować może specjalista, lecz niewykwalifikowany w takiej komunikacji czytelnik pozbawiony jest w zupełności narzędzi do oddzielenia treści tekstów Bator od prawdy na temat japońskiej rzeczywistości dnia codziennego. Przewina dezinformacji nie polega na kreowaniu tekstów - w mniejszej lub większej mierze świadomie - nieudolnych w manierze niefachowej. Cechy dużo bardziej destrukcyjne przejawiają relacje kompilowane sprawnie i gładko, w stopniu umożliwiającym im nawet udawanie fachowych, acz z unaoczniającymi się przy bliższym wglądzie poważnymi naruszeniami rzetelności formulacyjnej, kwalifikującymi owe teksty jednoznacznie do kategorii wytworów niedbałych. 


\section{Literatura}

Austin, J. L. (1962). How to Do Things With Words. Cambridge [Massachusetts]: Harvard University Press.

Bator, J. (2004). Japoński wachlarz. Warszawa: Twój Styl.

Bator, J. (2014). Rekin z parku Yoyogi. Warszawa: Grupa Wydawnicza „Foksal”.

Berger, P. L., Luckmann, T. (1983). Społeczne tworzenie rzeczywistości (tłum. J. Niżnik). Warszawa: Państwowy Instytut Wydawniczy.

Berne, E. (1999). W co grają ludzie. Psychologia stosunków międzyludzkich (tłum. P. Izdebski). Warszawa: Wydawnictwo Naukowe PWN.

Caillois, R. (1997). Gry i ludzie (tłum. A. Tatarkiewicz, M. Żurowska). Warszawa: Oficyna Wydawnicza „Volumen”.

Gall, W. (1961). Japonia - kraj kontrastów. Warszawa: Wiedza Powszechna.

Goffman, E. (2000). Człowiek w teatrze życia codziennego (tłum. H. Datner-Śpiewak, P. Śpiewak). Warszawa: Wydawnictwo „KR”.

Guiraud, P. (1974). Semiologia (tłum. S. Cichowicz). Warszawa: Wiedza Powszechna.

Huizinga, J. (1985). Homo ludens. Zabawa jako źródło kultury (tłum. M. Kurecka, W. Wirpsza). Warszawa: Czytelnik.

Jabłoński, A. (2009). Gry, procedury, przewidywalność - w kontekście polsko-japońskiej komunikacji międzykulturowej. Homo Ludens, 1(1), 103-112. Online: <http://ptbg.org.pl/dl/11/Arkadiusz\%20JAB\%C5\%81O\%C5\%83SKI\%2O-\%2O Gry,\%2oprocedury,\%2oprzewidywalno\%C5\%9B\%C4\%87\%20\%Е2\%80\%93\%20 w\%2okontek\%C5\%9Bcie\%2opolsko-japo\%C5\%84skiej\%2okomunikacji\%2O mi\%C4\%9gdzykulturowej.pdf $>$. Data dostępu: 24 sierpnia 2018.

Jabłoński, A. (2016). Japońskie alter ego. Jeszcze o antyinformacji w „narracjach niedbałych”. Homo Ludens, 9(1), 53-63. Online: <http:// ptbg.org.pl/dl/210/Arkadiusz\%20JAB\%C5\%81O\%C5\%83SKI\%20-\%2O Japo\%C5\%84skie\%2oalter\%2oego.\%20Jeszcze\%200\%20antyinformacji\%2ow\%20\%22narracjach\%2oniedba\%C5\%82ych\%22.pdf $>$. Data dostępu: 24 sierpnia 2018.

MacCannell, D. (2005). Turysta. Nowa teoria klasy próżniaczej (tłum. E. Klekot, A. Wieczorkiewicz). Warszawa: Muza.

Pawlikowska B. (2016). Blondynka w Japonii. Warszawa: Edipresse.

Ritzer, G. (2012). Magiczny świat konsumpcji (tłum. L. Stawowy). Warszawa: Muza. 
Rubach-Kuczewska, J. (1983). Życie po japońsku. Warszawa: Iskry.

Said, E. W. (2005). Orientalizm (tłum. M. Wyrwas-Wiśniewska). Poznań: Zysk i S-ka.

dr hab. Arkadiusz Jabłoński - prof. UAM, Zakład Japonistyki, Katedra Orientalistyki,

Wydział Neofilologii Uniwersytetu im. Adama Mickiewicza w Poznaniu

\section{Relacje orientalistyczne o Japonii a gra w antyinformację - studium przypadku}

Abstrakt: Relacje orientalistyczne (zwane relacjami niedbałymi) dotyczące Japonii i różnych przejawów kultury japońskiej zdają się stanowić nieunikniony składnik komunikacji społecznej w dobie powszechności i cykliczności przekazu masowego. Warto zatem pochylić się nad ich wartością informacyjną, w szczególności ze względu na możliwość stosunkowo tatwej weryfikacji faktów źródłowych, jaką społeczeństwo medialne współcześnie również zapewnia. W niniejszym artykule jako przykłady swoistej gry w antyinformację zostały przedstawione narracje orientalistyczne dostępne czytelnikowi polskiemu, autorstwa Joanny Bator i Beaty Pawlikowskiej. Pomimo bowiem wyraźnej niedbałości faktograficznej - widocznej w analizowanych tekstach już na pierwszy rzut oka - zdają się na ich przykładzie rysować pewne interesujące trendy w oglądzie świata poprzez beztroską i nieskrępowaną właściwie (acz nie zawsze: bezproduktywną) ludyczną aktywność formulacyjną, jakiej teksty te stanowią autentyczny i bezrefleksyjny przejaw.

Stowa kluczowe: gry komunikacyjne, komunikacja międzykulturowa, orientalizm, nieproduktywność 